zrównoważony rozwój społeczeństwa informacyjnego. Niezwykle ważnym aspektem jest dbanie o często pomijane grupy społeczne czy tereny słabiej rozwinięte. Długie rozmowy w kuluarach oraz ożywione zainteresowanie tematem były chyba najlepszym potwierdzeniem zaciekawienia uczestników konferencji.

Katarzyna Janczulewicz Instytut Bibliotekoznawstwa i Informacji Naukowej, Uniwersytet Ślaski

\title{
III Międzynarodowa Konferencja Naukowa „Nauka o informacji (informacja naukowa) w okresie zmian" Nauka o informacji a humanistyka cyfrowa (Warszawa, 11-12 maja 2015 r.)
}

W dniach 11-12 maja 2015 r. w Warszawie odbyła się III Międzynarodowa Konferencja Naukowa "Nauka o informacji (informacja naukowa) w okresie zmian” (Information Science in an Age of Change), zorganizowana przez Zakład Systemów Informacyjnych Instytutu Informacji Naukowej i Studiów Bibliologicznych Uniwersytetu Warszawskiego pod patronatem ISKO PL - International Society for Knowledge Organization Poland. Była to już kolejna edycja ${ }^{1}$ cyklicznie organizowanej od 2011 r. konferencji „Nauka o informacji (informacja naukowa) w okresie zmian”, której głównym celem jest monitorowanie zachodzących przemian, prezentacja nowych koncepcji i metod badawczych oraz projektowanych i wdrażanych nowych rozwiązań, a także wymiana doświadczeń badaczy z różnych dyscyplin nauki, zajmujących się problematyką rozwijania nowoczesnych technologii i ich zastosowań w różnych dziedzinach działalności badawczej i praktycznej. Strona internetowa konferencji prowadzona jest pod adresem http://www.lis.uw.edu.pl/nauka/.

W tym roku organizatorzy w szczególności skupili uwagę na relacjach między nauką o informacji a humanistyką cyfrową. Zakres tematyczny konferencji objął takie zagadnienia, jak: humanistyka cyfrowa jako przedmiot badań informatologicznych; narzędzia i środowisko cyfrowe dla humanistyki; społeczne i filozoficzne aspekty rewolucji cyfrowej; nowe technologie a dostęp do dziedzictwa kulturowego, naukowego i technicznego; cyfrowa humanistyka a Sieć Semantyczna; mobilny dostęp do informacji a potrzeby humanistyki cyfrowej; cyfrowa komunikacja naukowa; data literacy - kompetencje cyfrowe w zakresie gromadzenia, przetwarzania i danych oraz data librarianship - kompetencje i kształcenie bibliotekarzy jako pośredników w dostępie do danych badawczych; wizualizacja informacji i wiedzy w humanistyce; badania ilościowe i jakościowe mediów społecznościowych oraz piśmiennictwa cyfrowego; repozytoria danych na potrzeby cyfrowej humanistyki; wystawy wirtualne; zarządzanie i przechowywanie danych badawczych (data curation); cyfrowe publikowanie (e-publishing); centra i narzędzia cyfrowej humanistyki a biblioteki; kanały komunikacji w środowisku cyfrowym oraz zachowania informacyjne w środowisku cyfrowym.

Konferencję rozpoczęło uroczyste otwarcie w Sali Brudzińskiego w Pałacu Kazimierzowskim, gdzie też odbyły się wszystkie sesje pierwszego dnia. Słowo wstępne wygłosili: prof. Barbara

1 Poprzednie edycje miały miejsce w 2011 i w 2013 r. 
Sosińska-Kalata - przewodnicząca Komitetu Programowego Konferencji, prof. Elżbieta Barbara Zybert - dziekan Wydziału Historycznego UW, dr hab. Dariusz Kuźmina, prof.UW - dyrektor Instytutu Informacji Naukowej i Studiów Bibliologicznych UW oraz prof. Wiesław Babik z IINiB Uniwersytetu Jagiellońskiego reprezentujący ISKO PL. Przewodnicząca Komitetu Programowego po powitaniu uczestników konferencji, przekazała smutną wiadomość o śmierci prof. Wandy Pindlowej, nestorki środowiska polskich informatologów i wychowawcy wielu badaczy tej dyscypliny z kolejnych pokoleń, byłej dyrektor IINIB UJ, bliskiego współpracownika Instytutu warszawskiego, członka Rady Programowej i uczestnika dwóch poprzednich edycji konferencji. Pamięć Profesor Pindlowej uczczono minutą ciszy. Z uwagi na pogrzeb zaplanowany na następny dzień w Krakowie, w programie konferencji nastąpiło szereg zmian, a kilka wystąpień zostało odwołanych (Sabina Cisek, Magdalena Jaskowska, Diana Pietruch-Reizes).

W pierwszym dniu konferencji odbyły się cztery sesje plenarne. Trzy pierwsze, międzynarodowe, prowadzone były w języku angielskim. Pierwsza sesja, moderowana przez prof. B. Sosińską-Kalatę (IINiSB UW) i zatytułowana „Digital Humanities and Challenges for Information Science” (Humanistyka cyfrowa i wyzwania dla nauki o informacji) obejmowała cztery keynotes - wykłady zaproszonych gości, wprowadzające w temat przewodni konferencji: Trustworthiness in scholarly communications in the digital age: the situation of the humanities, wygłoszony przez Davida Nicholasa (CIBER Research, UK and Tomsk State University, Russia), This Time is Different, Indeed. A Reflection on Digital Humanities - Mieczysław Muraszkiewicz (Instytut Informatyki, Politechnika Warszawska), Digital Libraries \& Digital Humanities: Common Issues and New Perspectives zaprezentowany przez Widad Mustafę El Hadi (GERiiCO Research Team University of Lille 3 we Francji) i ostatni - Laurence Favier, reprezentującej tę samą jednostkę, co poprzedniczka - Humanities crowdsourcing: from digital information access to collaborative knowledge creation.

Wykład prof. Davida Nicholasa był poświęcony wpływowi Internetu na komunikację naukową. Przedstawione zostały w nim wnioski z przeprowadzonego przez CIBER międzynarodowego badania przeglądowego wśród 3650 naukowców reprezentujących różne dziedziny nauki, którego celem było ustalenie postaw badaczy wobec cyfrowych przemian następujących w komunikacji naukowej. Badania wykazały duże różnice między humanistami i przedstawicielami nauk przyrodniczych w zachowaniach informacyjnych i postawach wobec korzystania z cyfrowych form komunikacji w nauce. Generalnie obserwuje się bardziej zachowawcze postawy wśród humanistów i preferowanie przez nich tradycyjnych metod pracy i form upowszechniania jej wyników oraz znacznie większą skłonność do szybkiego wdrażania cyfrowego warsztatu pracy przez badaczy nauk ścisłych i przyrodniczych ${ }^{2}$.

Tematem wykładu prof. Mieczysława Muraszkiewicza były kontrowersje dotyczące konsekwencji rozwoju sztucznej inteligencji dla humanistyki i idei humanizmu. Prelegent postawił szereg pytań o zasadność obaw związanych z rozwojem AI i prognoz dotyczących symbiotycznej współpracy ludzi i maszyn oraz przyszłych zmian ewolucyjnych człowieka wywołanych przez jego fuzję z AI. Zwrócił uwagę, że obecnie pytania te pozostają otwarte, a więc konieczne jest śledzenie rozwoju sztucznej inteligencji i rozważne analizowanie konsekwencji wdrażania tej technologii w różnych obszarach ludzkiego życia.

Kolejne dwa wykłady zaprezentowały przedstawicielki GERiiCO Research Team - ośrodka badań dotyczących informacji i komunikacji na Uniwersytecie Lille 3 we Francji. Prof. Widad Mustafa El Hadi omówiła koncepcję humanistyki cyfrowej i jej powiązania z organizacją wiedzy. Przedstawiła też programy i projekty realizowane obecnie w ramach budowania i rozwoju humanistyki cyfrowej (m.in. TGIR Huma-Num, DARIAH i CLARIN), w ramach których prowadzone są też badania w zakresie organizacji wiedzy i jej wykorzystywania w e-humanistyce. $Z$ kolei prof. Laurence Favier skupiła uwagę na zmianach następujących pod wpływem coraz szerszego wykorzystywania w technologii cyfrowej w organizacji i metodologii badań humanistycznych. Zwróciła uwagę na coraz częstsze

${ }^{2}$ W niniejszym numerze ZIN publikujemy artykuł stanowiący zmodyfikowaną wersję wykładu Davida Nicholasa (zob. s. 7-19). [red.] 
wykorzystywanie crowdsourcingu w realizacji projektów badawczych e-humanistyki, zwiększanie liczby badaczy biorących udział w tych projektach oraz rozwój współpracy międzynarodowej. Zaprezentowała tzw. community based projects, np. GapVis, Alpheios, Mapping the Republic of Letters, które zostały stworzone i są kontynuowane przy udziale wielu osób z różnych krajów, skupionych wokół wspólnej idei. Charakterystyczną cechą takich projektów jest też otwartość (open source, open access). Prof. Favier omówiła również powiązania DH z nauką o informacji, wskazując, że e-humanistyka niesie wyzwania i zmiany m.in. w obszarach takich jak nowe formy edukacji, publikacji oraz nowe formy działania i nowe zadania bibliotek.

Kolejne dwie międzynarodowe sesje plenarne poświęcono kwestii przeformułowywania problemów badawczych nauki o informacji w odniesieniu do przestrzeni cyfrowej. Na pierwszą z nich, moderowaną przez dr hab. Remigiusza Sapę (IINIB UJ), składały się cztery referaty. Pierwszy, zatytułowany Digital technology vision 2015 and its human dimension, przedstawił Jarosław Chudziak (Accenture Strategy, Capability Network EALA Digital Business Strategy Lead). Omówił najważniejsze trendy w rozwoju technologii i usług cyfrowych skierowanych do biznesu, określone na podstawie badań opisanych w raporcie Accenture Technology Vision $2015^{3}$. Trendy te wskazują hasła: Internet jako nasz spersonalizowany świat; Nowoczesna Gospodarka, czyli o tym, że dziś sprzedajemy rezultaty, a nie rzeczy; Definiowanie Ekosystemu - redefiniowanie biznesu; Wiele Danych + Mądrzejsze Systemy = Lepszy Biznes oraz Współpraca Ludzi i Maszyn. Piotr Gawrysiak z Instytutu Informatyki, Politechniki Warszawskiej przedstawił humanistykę w świetle Big Data - Humanities and big data - exploiting the digital archives in the age of abundance. Zastanawiał się nad po raz kolejny dotykającą ludzkość obfitością informacji oraz dążeniem do digitalizacji wszystkiego wokół, zadając pytanie czy jest to możliwe i rzeczywiście potrzebne. W odniesieniu do zalewu danymi, wskazał na korzyści płynące z wizualizacji informacji, przedstawiając kilka ciekawych projektów, np. Similar Diversity Project czy Stanford Orbis Project. Magdalena Shishenkova (GERiiCO Research Team University of Lille 3, Francja) w referacie pt. Credibility of information: exploring a concept in the digital reality omówiła koncepcję wiarygodności informacji w Internecie. Przedstawiła tzw. mapę wiarygodności autorstwa Paula Matthewsa, zwracając uwagę, na znaczenie zdefiniowania koncepcji wiarygodności informacji dla badań nad zachowaniami informacyjnymi. Ostatnia prezentacja w sesji, autorstwa Anny Mierzeckiej (IINiSB UW) i Andriusa Šuminasa (Vilnius University, Faculty of Communication, Media Research Lab) była zatytułowana Academic Libraries Websites vs. Users'Needs. Tematem tej prezentacji były funkcje stron internetowych bibliotek akademickich i ocena ich realizacji przez witrynę Biblioteki Uniwersyteckiej w Warszawie. Przedstawione zostały wyniki badań przeprowadzonych na próbie 340 studentów przy wykorzystaniu metod sondażowych oraz testów eye-tracking, w których uczestniczyło 50 studentów.

W sesji trzeciej, moderowanej przez prof. Wiesława Babika (IINiB UJ), kontynuowany był wątek nowych problemów badawczych ewokowanych przez rewolucje cyfrową w nauce o informacji. Mariusz Luterek (IINiSB UW) omówił problematykę elektronicznej administracji w świetle koncepcji humanistyki cyfrowej, sygnalizując rolę bibliotek publicznych w niwelowaniu negatywnych konsekwencji podziału cyfrowego przez wspieranie obywateli w korzystaniu z informacji i usług publicznych online. Zaprezentował wyniki badania ankietowego przeprowadzonego wśród bibliotek publicznych w trzech województwach: mazowieckim, małopolskim oraz świętokrzyskim, które wykazały, że nie wszystkie biblioteki są gotowe do funkcji pełnienia roli pośrednika miedzy obywatelami i usługami e-government, przede wszystkim z powodów infrastrukturalnych i braku odpowiedniego przeszkolenia w tym zakresie. Z kolei Teresa Villaseñor Hernández (Facultad de Humanidades, Universidad Autónoma del Estado w Meksyku) w referacie Information science as a timeless subject: the transition from paperback to digital humanities in Mexico, przedstawiła meksykańskie środowisko badawcze nauki o informacji i prowadzone przez nie badania w zakresie e-humanistyki. Stwierdziła, że badacze humanistyki w Meksyku nadal chętniej korzystają ze źródeł tradycyjnych niż zdigitalizowanych. Humanistyka cyfrowa

\footnotetext{
${ }^{3}$ Zob. http://techtrends.accenture.com/us-en/it-technology-trends-2015.html
} 
dopiero rozwija się w tamtejszym środowisku naukowym. Uczestnicy konferencji zostali zapoznani ze sposobami budowania przez Meksyk repozytoriów, aplikacji i baz danych dla naukowców oraz działaniami rządu wspierającymi zachowanie dziedzictwa kulturowego i dokumentalnego. Szczególne miejsce zajmuje projekt Codex Mendoza (promowanie historii Meksyku za pomocą azteckiego kodeksu z XVI wieku) oraz internetowe katalogi z prehiszpańskimi artefaktami. Uczestnicy konferencji, korzystając z możliwości szerszego zapoznania się z mało znaną sytuacją bibliotek i nauki o informacji w tak odległym nam kraju, jak Meksyk, zadali ostatniej prelegentce szereg pytań.

Ostatnia sesja pierwszego dnia konferencji, zatytułowana „Społeczności wirtualne i dane cyfrowe w humanistyce i badaniach społecznych", obejmowała sześć wystąpień w języku polskim, a moderowana była przez prof. Marię Próchnicką (IINIB UJ). Sebastian Grabowski (Telekomunikacja Polska, Centrum Badawczo-Rozwojowe) w referacie zatytułowanym Społeczności programistyczne w obszarze Otwartych Interfejsów Programistycznych - Open API: przykłady i wnioski, nawiązał do wspomnianych wcześniej zagadnień crowdsourcingu, wskazując, że tworzenie otwartych interfejsów programistycznych, wokół których powstają wirtualne społeczności programistów, staje się niezwykle istotne dla rozwoju technologii komunikowania. Omówił zjawisko tworzenia się społeczności programistycznych (Twilio, Skype, Ribbit) skupiających ludzi z całego świata, dzięki którym obecnie w ciągu kilku godzin powstają nowe programy, których napisanie bez takiej współpracy zajęłoby jeszcze niedawno miesiąc, a nawet rok. Z kolei Remigiusz Sapa (IINiB UJ) przedstawił referat pt. Zarzadzanie indywidualnymi kolekcjami informacji naukowej $w$ humanistyce $w$ świetle piśmiennictwa anglojęzycznego, skupiając uwagę na rozpoznania sposobu ujmowania i zakresu eksploracji problematyki zarządzania indywidualnymi kolekcjami informacji naukowej w humanistyce. Analiza tych zagadnień przeprowadzona została na podstawie krytycznej analizy piśmiennictwa badawczego, która umożliwiła identyfikację kontekstów, w których problematyka ta pojawia się, m.in. proces badawczy, wykonywanie zawodu naukowca, cyfrowa humanistyka, biblioteki, zachowania informacyjne, wykorzystywanie technologii. W trzecim referacie pt. O teorii (cyber)gatunków Marek Nahotko (IINiB UJ) w kontekście teorii gatunków (tekstów użytkowych) wyjaśnił pojęcie cybergatunku i omówił transformacje tego typu wypowiedzi, następujące pod wpływem stosowania nowych technologii. Odwołując się z kolei do teorii innowacji nakreślił konsekwencje szybkiego rozwoju nowych technologii dla destrukcji tradycyjnych gatunków tekstu i rozwoju gatunków elektronicznych. W następnym wystąpieniu Małgorzata Góralska (IINiB UWr) przedyskutowała problem ulotności i dynamizmu technologii cyfrowej oraz oddziaływania tych jej własności na trwałość pamięci utrwalonej w nowych mediach. W referacie pt. Imperatyw pamięci $i$ akceptacja zapomnienia $w$ epoce cyfrowej, przybliżając problem elektrośmieci wskazała na dwie strategie mające na celu utrwalanie informacji - próbę stworzenia trwałego nośnika (na kamieniu, szkle, diamencie) albo cykliczne przenoszenie zapisanych informacji na nowe nośniki, dostosowywane do dostępnych aktualnie technologii. Pytanie, które w tym kontekście postawiła korespondowało z wcześniejszymi rozważaniami P. Gawrysiaka: czy jest w nas akceptacja dla zapominania i usuwania informacji, czy rzeczywiście wszystko musimy bezustannie powielać i nadawać mu formę cyfrową? W piątym w tej sesji referacie Wiesław Babik (IINiB UJ) podjął rozważania na temat organizacji wiedzy, jej miejsca w nauce o informacji, statusu, celów, najważniejszych badaczy (Organizacja informacji i wiedzy - pole badawcze nauki o informacji). Sesję zakończył referat Technologie w zarzadzaniu i dzieleniu się wiedza i informacja - w świetle badań wśród przedstawicieli różnych nauk przedstawiony przez Marzenę Świgoń (Instytut Historii i Stosunków Międzynarodowych UWM w Olsztynie), w którym omówiła ona wyniki swoich badań. Celem ich było ustalenie z jakich narzędzi cyfrowych korzystają polscy naukowcy w swojej pracy i komunikacji z kolegami. Badania zostały przeprowadzone na podstawie ankiety rozesłanej elektronicznie do polskich naukowców zrejestrowanych w bazie „Ludzie nauki" za pośrednictwem Ośrodka Przetwarzania Informacji. Na ankietę odpowiedziało ok.1.5 tys. osób, a na podstawie uzyskanych danych M. Świgoń stwierdziła, że naukowcy najczęściej korzystają z poczty elektronicznej, z serwisów dla naukowców (ResearchGate, Academia.edu) dużo rzadziej. Podobnie jak w badaniach D. Nicholasa, również w tych badaniach uwidoczniła się duża różnica między 
badaczami nauk humanistycznych a specjalistami innych dziedzin nauki w stopniu wykorzystywania technologii cyfrowych. Badania pokazały równocześnie, że polscy humaniści częściej niż ich koledzy zajmujący się naukami przyrodniczymi i ścisłymi, wykorzystują serwisy społecznościowe, takie jak Facebook, LinkedIn, Twitter. Generalnie jednak, serwisy społecznościowe, fora dyskusyjne, Slideshare czy repozytoria również nie cieszą się dużym zainteresowaniem naukowców. Rzadko prowadzą oni swoje strony internetowe lub blogi (tylko 7\% przebadanych ma bloga). Z badań płynie wniosek, że technologie pełnią drugorzędną rolę $\mathrm{w}$ dzieleniu się wiedzą w polskim środowisku naukowym.

Obrady drugiego dnia konferencji miały miejsce w Bibliotece Uniwersyteckiej w Warszawie i zostały zorganizowane w pięciu sesjach tematycznych. Pierwsza, moderowana przez prof. Jadwigę Woźniak-Kasperek (IINiSB UW), miała charakter plenarny, a w jej trakcie wygłoszono pięć referatów. Hasłem przewodnim tej sesji były „Badania humanistyki cyfrowej z perspektywy informatologicznej”. Sesję rozpoczęło wystąpienie B. Sosińskiej-Kalaty (IINiSB UW) Humanistyka cyfrowa w piśmiennictwie badawczym nauki o informacji. Celem badań, których wyniki przedstawiła autorka, była ocena stopnia zainteresowania humanistyką cyfrową w środowisku badaczy nauki o informacji oraz identyfikacja podejmowanych problemów badawczych z tego zakresu. Na podstawie piśmiennictwa zarejestrowanego w bazie Library, Information Science and Technology Abstracts autorka wyodrębniła 123 publikacje, w tym 77 artykułów naukowych, których tematyką były zagadnienia związane z humanistyką cyfrową. Na podstawie analizy tego piśmiennictwa wskazane zostały m.in.: rozkład publikacji w czasie, udział publikacji w poszczególnych językach, rozkład czasopism, w których podejmowana była tematyka e-humanistyki, główne kategorie tematyczne badań, afiliacje autorów. W kolejnym wystąpieniu Mirosław Górny (Instytut Językoznawstwa Uniwersytetu im. Adama Mickiewicza w Poznaniu) i Zbigniew Osiński (IINiB UMCS) zaprezentowali założenia projektu badawczego realizowanego wraz z Ewą Głowacką (IINiB UMK) i Małgorzatą Kisilowską (IINiSB UW). Przedmiotem wystąpienia była koncepcja modelu indywidualnej przestrzeni informacyjnej, jako narzędzia badania procesów informacyjnych, ale również w odniesieniu do problematyki cyfryzacji humanistyki. Autorzy zaprezentowali interesujące propozycje zdefiniowania tego pojęcia zarówno w szerokim kontekście, jak i w odniesieniu do procesów informacyjnych realizowanych przez naukowców za pomocą nowoczesnych technologii informacyjnych. Marta Grabowska (IINiSB UW) w referacie pt. Koncepcja zbiorów big data dla tzw. humanistyki cyfrowej, narzędzia do ich analizy oraz warunki korzystania $z$ tej infrastruktury informacyjnej dokonała charakterystyki terminu Big Data, czyli zbiorów danych, które nie pozwalają na zastosowanie tradycyjnych metod i narzędzi do ich przetwarzania z uwagi na ich dużą wielkość, dynamiczny przyrost, formalną heterogeniczność oraz problemy z oceną wiarygodności. Autorka omawiając te problemy przyjęła perspektywę techniczną, tzn. dużą uwagę skupiła na narzędziach służących do analizy i zarządzania tego rodzaju zbiorami danych. W kolejnym wystąpieniu Łukasz Iwasiński (IINiSB UW) podjął problem tzw. danetyzacji rzeczywistości, czyli zjawiska interpretacji wszelkich obszarów rzeczywistości poprzez pryzmat danych reprezentujących ich stany oraz wniosków płynących na podstawie ich analizy. Celem wystąpienia było zidentyfikowanie społecznych zagrożeń będących wynikiem takich założeń epistemologicznych. W ostatnim wystąpieniu, podczas sesji plenarnej, Teresa Święćkowska (IINiSB UW) poruszyła problem ochrony prawno-autorskiej w odniesieniu do kolekcji cyfrowych. W referacie Choroba sieroca humanistyki cyfrowej czyli o problemach z niewyjaśnionymi prawami autorskimi autorka skupiła się na specyficznym rodzaju dokumentów, którymi są dzieła osierocone oraz wskazała na możliwe kierunki zmian w kontekście ustawy o prawie autorskim w Polsce. Sesję zakończyło wystąpienie sponsora - Wydawnictwa Helion, w którym zaprezentowano ofertę internetowej wypożyczalni książek elektronicznych.

Kolejne wystąpienia zostały zorganizowane w dwóch blokach sesji równoległych. W sesji pt. „Informacyjne usługi biblioteczne wobec wyzwań humanistyki cyfrowej", moderowanej przez dr hab. Małgorzatę Kisilowską (IINiSB UW), wygłoszono pięć referatów, których wspólnym mianownikiem były formy uczestnictwa bibliotek i bibliotekarzy jako pośredników w dostępie do zasobów cyfrowej humanistyki oraz jako badaczy tego zjawiska. Katarzyna Materska (Biblioteka UKSW) poruszyła 
problem wpływu cyfryzacji humanistyki na koncepcję biblioteki akademickiej oraz kwestię zmian w zakresie świadczonych przez te instytucje usług informacyjnych. W tym nurcie mieściły się również wystąpienia Lilianny Nalewajskiej (BUW) oraz Elżbiety Sroki (IBiIN UŚ). L. Nalewajska w referacie pt. Przyszłość ustug informacyjnych w polskich bibliotekach akademickich na tle rozwoju humanistyki cyfrowej przedstawiła wyniki badań ankietowych przeprowadzonych wśród bibliotek akademickich w Polsce na temat zakresu i form świadczenia usług informacyjnych w dobie zmian, jakie nastąpiły w prowadzeniu działalności naukowej na skutek upowszechnienia się nowoczesnych technologii informacyjnych i dominacji Internetu jako głównego środowiska obiegu informacji w nauce. E. Sroka w referacie pt. Otwarte zasoby specjalistyczne bibliotek głównych wyższych uczelni ekonomicznych. Analiza. Wybrane zagadnienia przedstawiła wyniki przeprowadzonych badań związanych z popularyzacją otwartych zasobów jako źródeł informacji specjalistycznej. Inną perspektywę reprezentowały wystąpienia Jadwigi Woźniak-Kasperek (IINiSB UW) wraz z Bartłomiejem Włodarczykiem (Biblioteka Narodowa) oraz Marcina Roszkowskiego (IINiSB UW). W pierwszym przypadku autorzy zaprezentowali przykłady włączania się bibliotek w inicjowanie i realizację projektów badawczych z obszaru cyfrowej humanistyki. W drugim, M. Roszkowski scharakteryzował rodzaj kompetencji informacyjnych bibliotekarzy obejmujących korzystanie z danych, które określa się mianem data literacy. Autor zaprezentował również zestaw pożądanych umiejętności w tym zakresie oraz przykładowe formy edukacji bibliotekarzy dotyczące data literacy.

Równolegle do sesji poświęconej usługom bibliotecznym odbyła się sesja zatytułowana "Cyfrowa wizualizacja informacji”, moderowana przez dr hab. Mirosława Górnego, prof. UAM. Jej przedmiotem były formy i metody wizualizacji informacji zarówno w odniesieniu do informacji naukowej, jak i kolekcji w ramach szeroko rozumianej humanistyki cyfrowej. Daria Rzepiela (doktor nauk o sztuce i niezależny twórca) przedstawiła interesujące wizualizacje dziejów budynku Teatru Wielkiego, zrealizowane przez nią w ramach projektu „Być Wielkim”, do których opracowania wykorzystała zgromadzoną na potrzeby projektu kolekcję materiałów ikonograficznych. Anna Kamińska (IINiSB UW) $\mathrm{w}$ referacie pt. Wizualne formy prezentacji informacji w humanistyce $i$ ich miejsce $w$ sformalizowanej cyfrowej komunikacji naukowej podjęła temat metod i form wizualizacji informacji naukowej oraz m.in. kwestie multimedialności treści naukowych. Kamil Stępień (IINiB UMCS) w wystąpieniu zatytułowanym Strategie wyszukiwania obrazów i obrazem. Wyszukiwanie wizualne w przestrzeni $W W W$ podjął problem metod wyszukiwania materiałów ikonograficznych w środowisku sieciowym i reprezentacji informacji, w odniesieniu do tej klasy zasobów informacyjnych. Autor przedstawił interesujące przykłady funkcjonujących rozwiązań i narzędzi sieciowych oferujących nowatorskie kryteria wyszukiwania informacji. Zdzisław Dobrowolski (IINiSB UW) w referacie pt. Wizualizacja kontekstu informacyjnego $w$ wirtualnych galeriach $i$ muzeach poruszył kwestię architektury informacji we wspomnianych miejscach, skupiając się na problemie kontekstualizacji z wykorzystaniem elementów graficznych i funkcjonalności serwisów WWW je wykorzystujących.

W części popołudniowej zorganizowano dwie sesje tematyczne. Z uwagi na konieczność zmian w programie, w sesji pt. „Zarządzanie informacją i wiedzą”, moderowanej przez dr hab. Katarzynę Materską, prof.UKSW, wygłoszono dwa referaty. Były to: wystąpienie Marii Przastek-Samokowej (IINiSB UW) poświęcone slawistyce cyfrowej oraz referat Anny Myśliwskiej (Biblioteka Narodowa) pt. Infobroker w środowisku cyfrowym - analiza zachowań informacyjnych w procesie bibliotecznej mediacji. Równolegle odbyła się sesja pt. „Narzędzia informacyjne i cyfrowe zasoby wiedzy”, moderowana przez prof. Jadwigę Woźniak-Kasperek (IINiSB UW). Grzegorz Gmiterek (IINiSB UW) omówił sposoby wykorzystania technologii rzeczywistości rozszerzonej w książkach naukowych i popularnonaukowych oraz w literaturze pięknej. Bożena Bednarek-Michalska (BU UMK) w referacie pt. Repozytoria surowych danych badawczych dla humanistyki wskazała na znaczenie publikowania tzw. surowych danych badawczych w kontekście optymalizacji obiegu informacji we współczesnej nauce i możliwość ponownego ich wykorzystania na potrzeby kolejnych badań naukowych. Autorka skupiła się na kwestiach prawnych i organizacyjnych w odniesieniu do repozytoriów danych badawczych w Polsce 
i Europie. Przedmiotem wystąpienia Dominiki Palecznej (IINiSB UW), zatytułowanego Metody badania użyteczności systemów informacyjnych, były systemy informacyjne typu discovery. Celem badań autorki była identyfikacja i analiza elementów interfejsu użytkownika w tej klasie systemów oraz wybrane formy interakcji z użytkownikiem, które oceniano z punktu widzenia ich użyteczności.

Konferencję zakończyła dyskusja panelowa, prowadzona przez przewodniczącą Komitetu Programowego - prof. B. Sosińską-Kalatę, a do uczestnictwa w niej zaproszeni zostali obecni drugiego dnia konferencji moderatorzy wszystkich sesji: dr hab. Katarzyna Materska, prof. UKSW (Biblioteka UKSW), prof. Jadwiga Woźniak-Kasperek, dr hab. Małgorzata Kisilowska (obie z IINiSB UW) i dr hab. Mirosław Górny, prof. UAM (IJ UAM). Moderatorzy sesji dyskutowali na temat poruszonych podczas konferencji zagadnień i podsumowali moderowane przez siebie sesje, zachęcając obecnych do podjęcia dyskusji. Wśród końcowych wniosków sformułowane zostały m.in. następujące tezy: humanistyka cyfrowa nie jest nową dyscypliną nauk humanistycznych, ale nową przestrzenią badawczą i informacyjną (J. Woźniak-Kasperek); faktyczny przełom w uprawianiu humanistyki wiąże się z wykorzystaniem w niej technik eksploracji wielkich zasobów danych (big data) (M. Grabowska); obecnie w praktykach badawczych humanistów widoczne jest najczęściej przenoszenie zachowań i postaw tradycyjnych do przestrzeni cyfrowej; rozwój humanistyki cyfrowej otwiera nowe pola badań dla nauki o informacji, a równocześnie wymaga rewizji programów kształcenia praktyków, po to, aby profesjonalistom informacji zapewnić kompetencje odpowiednie do sprawnej obsługi potrzeb informacyjnych nie tylko badaczy e-humanistyki, ale całego środowiska naukowego, którego warsztat badawczy i komunikacja w coraz większym stopniu migrują do przestrzeni cyfrowej (B. Sosińska-Kalata).

Na zakończenie przewodnicząca Rady Naukowej Konferencji, prof. B. Sosińska-Kalata podziękowała wszystkim uczestnikom i komitetowi organizacyjnemu. Podczas dwóch dni obrad w dziewięciu sesjach wygłoszono łącznie 37 referatów. Konferencja zgromadziła uczestników z pięciu państw (Francja, Meksyk, Wielka Brytania, Litwa i Polska), z dwóch kontynentów (Europa i Ameryka Północna). Organizatorzy zapowiedzieli publikację wygłoszonych referatów.

Monika Halasz-Cysarz Marcin Roszkowski Instytut Informacji Naukowej i Studiów Bibliologicznych Uniwersytet Warszawski

Nadestano: 10.07.2015.

\section{Ogólnopolska Konferencja Naukowa „Homo Communicativus. Przestrzeń informacyjna współczesnej nauki" (Toruń, 25-26 czerwca 2015 r.)}

W czerwcu 2015 r. już po raz drugi w Instytucie Informacji Naukowej i Bibliologii Uniwersytetu Mikołaja Kopernika w Toruniu zorganizowano konferencję „Homo Communicativus”. W zamierzeniu

\footnotetext{
4 Pierwsza Ogólnopolska Interdyscyplinarna Konferencja Naukowa Homo communicativus z podtytułem Współczesne oblicza komunikacji i informacji, odbyła się w Toruniu w dniach 24-25. czerwca 2013 r.
} 